\title{
Analysis of the Impact of Zakat, Infak, and Sadaqah Distribution on Poverty Alleviation Based on the CIBEST Model (Case Study: Jogokariyan Baitul Maal Mosque, Yogyakarta)
}

\author{
Salahuddin El Ayyubi and Henni Eka Saputri \\ Bogor Agricultural University
}

\begin{abstract}
The Special Region of Yogyakarta is one of the provinces with a high incidence of poverty on Java Island. The number of mosques and the increase of zakat funds, infak, and sadaqah each year is not sufficient to reduce the number of those in poverty. If the mosque is able to manage the zakat, infak, and sadaqah funds well, it can be predicted that the mosque would reduce poverty and increase the welfare of the community. This study aims to analyze the impact of zakat, infak, and sadaqah distribution in reducing poverty based on the Center for Islamic Business and Economic Studies (CIBEST) model (case study: Jogokariyan Baitul Maal Mosque, Yogyakarta). The results of the study indicate that there is an increase in welfare and a decrease in material poverty, spiritual poverty, and absolute poverty, as seen from changes in the Islamic CIBEST's poverty indexes for mustahik households.
\end{abstract}

Keywords: CIBEST Model, Jogokariyan Mosque, Poverty, ZIS

\section{INTRODUCTION}

The Special Region of Yogyakarta has one of the highest proportions of poor people out of all the provinces on Java Island. A total of 14.55 percent of the people living in Yogyakarta Special Region are classed as poor (CBS, 2017).

According to the data and in view of the reality regarding poverty nowadays, there should be a solution or instrument with which to alleviate it. Islam as a comprehensive (syaamil) religion contains a range of special instruments, the aim of which are the creation of economic justice; as such, they can be used to reduce poverty and improve the welfare of society. These instruments are zakat, infak, and sadaqah (ZIS). According to research by BAZNAS, the potential national zakat in 2015 was 2.4 percent of Gross Domestic Product (GDP), or approximately 286 trillion rupiahs. If the target for potential zakat is 3.4 percent of GDP, then the potential national zakat for 2016 would have been 442 trillion rupiahs.

Indonesia, as the country with the world's largest Muslim population, has large numbers of mosques, including in remote areas, and there have been mosques standing firmly in Indonesia since the first arrival of Islam. According to the Directorate General of Islamic Society Guidance, Ministry of Religious Affairs, Republic of Indonesia (2017), there are 221,095 mosques in Indonesia. The existence of mosques as zakat institutions, or of mosques that contain an institution to manage zakat, infak, and sadaqah, means there is great potential for them to collect ZIS funds from their communities. Greater amounts of ZIS funds encourage ZIS management to work more professionally. The government of Indonesia responded to that encouragement by Law No. 23/2011 on Zakat Management.

One such mosque that has a particular institution for managing ZIS funds is Jogokariyan Baitul Maal Mosque, 
Yogyakarta. Jogokariyan Mosque formed baitul maal to collect funds from communities and also to distribute them to the communities. The ZIS funds collected by baitul maal are distributed in order to help the economy and small enterprises within the community in the form of qardh (loan) or hibah (voluntary gift) for those who meet the relevant criteria. As Beik and Arsyianti (2016) explained, the aspects of material necessity and spiritual should harmonize in order to measure poverty and welfare from the perspective of Islam. Hence, a model is needed to measure these material and spiritual aspects, which is the function of the Center for Islamic Business and Economic Studies (CIBEST) model.

\section{LITERATURE REVIEW}

Research has been carried out to analyze the impact of zakat distribution on the alleviation of poverty. The very first research on the CIBEST model was conducted by Beik and Arsyianti (2015) and entitled "Construction of CIBEST Model as Measurement of Poverty and Welfare Indices From Islamic Perspective." The study explained that the concept of poverty and welfare as seen from the Islamic perspective comprises not only the material dimension but also the spiritual aspect. This research successfully formulated the CIBEST model as consisting of a welfare index, material poverty index, spiritual poverty index, and absolute poverty index. These indexes are based on the CIBEST quadrant concept that represents the Islamic concepts and perspectives of poverty and welfare.

Pratama (2015) attempted to use the CIBEST model to analyze the role of zakat for poverty alleviation. Referring to the case of Bogor regency, the study showed that following completion of a program that had been implemented with zakat, 63.7 percent of households were able to fulfill their material and spiritual needs. This was reflected through decreases in the material, spiritual, and absolute poverty indexes of 49.6, 1.6, and 12.3 percent, respectively, alongside an increase in the welfare (falah) index.

Attempts to use the CIBEST model to analyze the role of zakat for poverty alleviation have also been made by Mushlihah (2016). Examining the case of Bogor city, the study revealed that after completing a program implemented with zakat, 640 percent of households were able to fulfill their material and spiritual needs. This was reflected in decreases in the material, spiritual, and absolute poverty indexes of $62.16,68.18$, and 83.87 percent, respectively, along with an increase in the welfare (falah) index.

\section{METHODOLOGY}

This research was carried out with 100 respondents at Jogokariyan Baitul Maal Mosque, Yogyakarta during April 2017. Both primary and secondary data have been used in the research, with quantitative and descriptive analysis employed as the method of analysis. The tool used for analysis is the Islamic poverty index of CIBEST Bogor Agricultural University (IPB).

The calculations used in this research are the values for Material Value (MV), or household poverty line, and household income per month. MV is used to measure the minimum standard of material that should be consumed by the household. The value of MV is obtained by multiplying the price of goods and services $(\mathrm{Pi})$ consumed by the minimum amount of goods and services needed (Mi). Mathematically, MV can be expressed as follows:

$$
M V=\sum_{i=1}^{n} \mathrm{PiMi}
$$

where

MV : the minimum amount of material that should be consumed by the 
household (expressed in rupiahs or other currencies), otherwise known as the material poverty line.

$\mathrm{Pi}$ : the price of goods and services (expressed in rupiahs or other currencies)

$\mathrm{Mi}$ : the minimum amount of goods and services needed.

However, due to a limitation meaning that a survey was not attempted in this research, the value of MV employed is therefore the existing value, which is the household poverty line per capita per month for the average household size. The average household size was obtained as a ratio of the total population against the number of households in the researched region (Tsani, 2010).

The poverty line for Yogyakarta city for the period 2014-15 was 366,520 (CBS Yogyakarta city, 2017). The spiritual poverty line, or Spiritual Value (SV), is obtained based on the spiritual necessity indicator and the fulfillment of the five variables that make up the spiritual score: shalat (prayer), zakat, fasting, neighborhood, and government policy. A Likert scale with responses ranging from 1 through 5 was used to obtain a score for the above-mentioned variables, as shown in Table 1.

Table 1. Spiritual Indicators

\begin{tabular}{|c|c|c|c|c|c|c|}
\hline \multirow{2}{*}{ Variables } & \multicolumn{5}{|c|}{ Likert Scale } & \multirow{2}{*}{$\begin{array}{l}\text { Spritual } \\
\text { Standard }\end{array}$} \\
\hline & 1 & 2 & 3 & 4 & 5 & \\
\hline Prayer & $\begin{array}{l}\text { Blocking } \\
\text { others to } \\
\text { pray }\end{array}$ & $\begin{array}{l}\text { Against the } \\
\text { concept of } \\
\text { prayer }\end{array}$ & $\begin{array}{l}\text { Performing } \\
\text { obligatory } \\
\text { prayer but } \\
\text { not on } \\
\text { regular } \\
\text { basis }\end{array}$ & $\begin{array}{l}\text { Performing } \\
\text { obligatory } \\
\text { prayer but } \\
\text { not in a } \\
\text { congregation }\end{array}$ & $\begin{array}{l}\text { Performing } \\
\text { obligatory } \\
\text { prayers in a } \\
\text { congregation } \\
\text { and } \\
\text { performing } \\
\text { sunnah } \\
\text { prayer }\end{array}$ & \multirow{5}{*}{$\begin{array}{c}\text { Average } \\
\text { score for } \\
\text { spiritually } \\
\text { poor } \\
\text { household } \\
\text { is equal to } \\
3(\mathrm{SV}=3)\end{array}$} \\
\hline Fasting & $\begin{array}{l}\text { Blocking } \\
\text { others to } \\
\text { undertake } \\
\text { fasting }\end{array}$ & $\begin{array}{l}\text { Against the } \\
\text { concept of } \\
\text { fasting }\end{array}$ & $\begin{array}{l}\text { Not fully } \\
\text { performing } \\
\text { obligatory } \\
\text { fasting }\end{array}$ & $\begin{array}{l}\text { Performing } \\
\text { only } \\
\text { obligatory } \\
\text { fasting }\end{array}$ & $\begin{array}{l}\text { Performing } \\
\text { obligatory } \\
\text { fasting and } \\
\text { sunnah } \\
\text { fasting }\end{array}$ & \\
\hline $\begin{array}{l}\text { Zakat and } \\
\text { Infak }\end{array}$ & $\begin{array}{l}\text { Blocking } \\
\text { others to } \\
\text { pay zakat } \\
\text { and infak }\end{array}$ & $\begin{array}{l}\text { Against the } \\
\text { concept of zakat } \\
\text { and infak }\end{array}$ & $\begin{array}{l}\text { Not paying } \\
\text { infak at } \\
\text { least once } \\
\text { in a year }\end{array}$ & $\begin{array}{l}\text { Paying zakat } \\
\text { al-fitr and } \\
\text { zakat al-maal }\end{array}$ & $\begin{array}{l}\text { Paying zakat } \\
\text { al-fitr, zakat } \\
\text { al-maal, and } \\
\text { infak }\end{array}$ & \\
\hline $\begin{array}{l}\text { Household } \\
\text { Environment }\end{array}$ & $\begin{array}{l}\text { Forbid } \\
\text { ibaadah }\end{array}$ & $\begin{array}{l}\text { Against } \\
\text { implementation } \\
\text { of ibaadah }\end{array}$ & $\begin{array}{l}\text { Consider } \\
\text { ibaadah as } \\
\text { private } \\
\text { matter for } \\
\text { household } \\
\text { member }\end{array}$ & $\begin{array}{l}\text { Support } \\
\text { execution of } \\
\text { ibaadah }\end{array}$ & $\begin{array}{l}\text { Creating } \\
\text { environment } \\
\text { which } \\
\text { obligates } \\
\text { execution of } \\
\text { ibaadah }\end{array}$ & \\
\hline $\begin{array}{l}\text { Government } \\
\text { Policy } \\
\text { Environment }\end{array}$ & $\begin{array}{l}\text { Forbid } \\
\text { ibaadah }\end{array}$ & $\begin{array}{l}\text { Against } \\
\text { implementation } \\
\text { of ibaadah }\end{array}$ & $\begin{array}{l}\text { Consider } \\
\text { ibaadah as } \\
\text { private } \\
\text { matter }\end{array}$ & $\begin{array}{l}\text { Support } \\
\text { execution of } \\
\text { ibaadah }\end{array}$ & $\begin{array}{l}\text { Creating } \\
\text { environment } \\
\text { which } \\
\text { obligates } \\
\text { execution of } \\
\text { ibaadah }\end{array}$ & \\
\hline
\end{tabular}

Source: Beik and Arsyianti (2015)

Table 1 shows that the average SV score for a spiritually poor household is equal to three. Thus, if a household's score is lower than or equal to three, it can be categorized as being spiritually poor. The value of $\mathrm{SV}$ is obtained using the following formula: 


$$
H i=\frac{V p+V f+V z+V h+V g}{5}
$$

where

Hi : Actual score of household of first member

$\mathrm{Vp}:$ Shalat score

Vf : Fasting score

$\mathrm{Vz}:$ Zakat and infak score

$\mathrm{Vh}$ : Work environment score

$\mathrm{Vg}$ : Government policy score

\section{CIBEST Model}

As Beik and Arsyianti (2016) argued, using the definitions of material poverty, spiritual poverty, and absolute poverty, a quadrant can be formed, called the CIBEST IPB quadrant. The CIBEST quadrant was formed based on research by the Center for Islamic Business and Economic Studies and Sharia Economics Department of IPB in 2013 into the concept of the Islamic Poverty Line, and is illustrated in Figure 1.

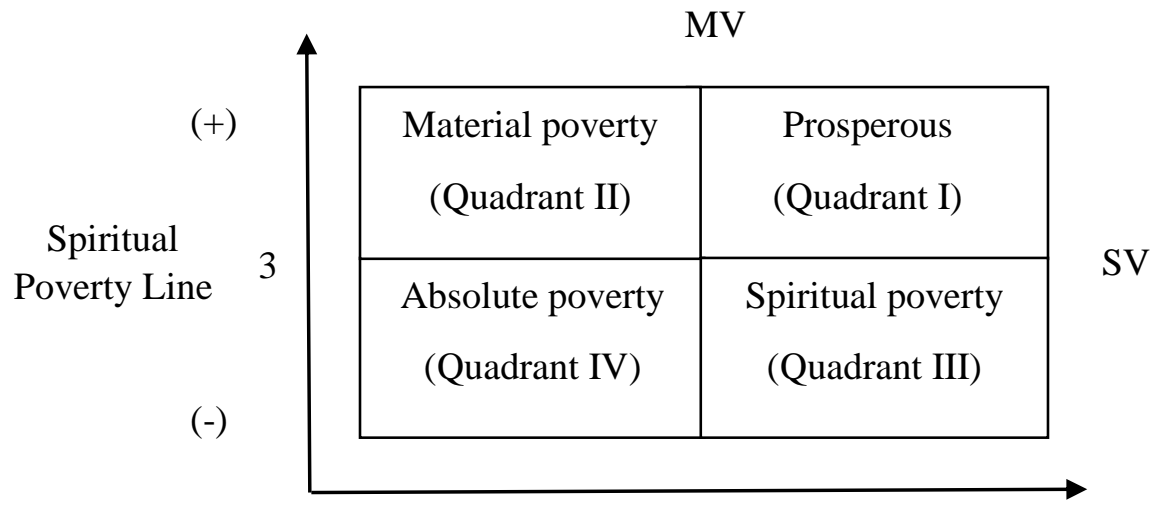

$(-)$

Material Poverty Line

$(+)$

Source: Beik and Arsyianti (2016)

Figure 1. CIBEST Quadrant

As shown in Figure 1, there are four areas in the CIBEST quadrant: prosperous, spiritual poverty, material poverty, and absolute poverty. Material needs are given by the horizontal axis and spiritual needs are given by the vertical axis. There are (+) and (-) signs shown against both the horizontal and vertical axes. A (+) symbol indicates that a household fulfills its material and/or spiritual needs well, while a (-) symbol indicates a lack of either material or spiritual needs fulfillment for a household.

The first quadrant depicts the condition of a prosperous household, wherein the household is fulfilling both its material and spiritual needs. It can be seen in Figure 2 that the first quadrant has a positive (+) symbol for both the material poverty and spiritual poverty lines. The depiction of quadrant I as classifying a prosperous household is found in the Qur'an Surah An-Nahl, verse 97, which is translated as follows:

"Whosoever doeth right, whether
male or female, and is a believer,
him verily we shall quicken with
good life, and We shall pay them a
recompense in proportion to the
best of what they used to do" (QS.
An-Nahl: 97).

The second quadrant shows a household condition that combines negative material needs fulfillment with positive spiritual fulfillment, as shown by the (-) symbol on the material poverty line and the (+) symbol on the spiritual poverty line. This type of household is therefore unable to meet its material needs but is 
able to fulfill its spiritual needs. This is explained by Allah SWT through Surah Al-Baqarah verse 155 , which is translated as follows:

\section{"And surely We shall try you with something of fear and hunger, and loss of wealth and lives and crops; but give glad tidings to the steadfast”(QS. Al-Baqarah: 155).}

The third quadrant shows the condition of a household that is spiritually poor but materially rich. This third quadrant is labeled in Figure 1 with a (-) symbol on the spiritual poverty line and a (+) symbol on the material poverty line, meaning that the household is not able to fulfill its spiritual needs but is able to meet its material needs. This condition is explained in Surah Al-AN'am verse 44, with the translation as follows:

"Then, when they forgot that whereof they had been reminded, We opened unto them the gates of all things till, even as they were rejoicing in that which they were given, We seized them unawares, and lo! they were dumbfounded" (QS. Al-An'am: 44).

The fourth quadrant indicates the absolute poverty condition for a household. In Figure 1 this fourth quadrant is labeled with a (-) symbol on both the spiritual and material poverty lines, meaning it cannot fulfill either its material or its spiritual needs. This condition is explained by Allah's commandment in Surah Thaha verse 124, translated as follows:

"But he who turneth away from remembrance of $\mathrm{Me}$, his will be a narrow life, and I shall bring him blind to the assembly on the Day of Resurrection" (QS. Thaha: 124).

As Beik and Arsyianti (2016) argued, the unit of analysis within the
CIBEST indexes is the household. This is because Islam considers the household to be the smallest unit in the community, and it thus shall be seen as a whole unity.

As Beik and Arsyianti (2016) argued, the advantage of the CIBEST quadrant relates to the mapping of households' conditions, in order that appropriate development programs can be suggested, especially in terms of pushing households currently in quadrants II, III, and IV toward the first quadrant (i.e., prosperous). A household in the second quadrant is materially poor, so the appropriate poverty alleviation program here comprises skills and ability empowerment, along with ensuring effective access to capital and guidance for businesses. For households in the third quadrant, which are spiritually poor, the appropriate program would address how to engage with and follow Islamic teachings well. A household in the fourth quadrant is absolutely poor; thus, the first things that should be fixed are the ruhiyah and mental, then fix the economic life. Building noble character is the most precious form of capital for transforming the dhuafa groups to be more prosperous.

\section{Welfare Index}

The Welfare Index (W) is used to determine those households for inclusion in quadrant I. Households in this quadrant are said to be prosperous. The value of $\mathrm{W}$ can be obtained using the following formula:

$$
\mathrm{W}=\frac{w}{N}
$$

where

$$
\begin{aligned}
\mathrm{W} & : \text { Welfare index: } 0 \leq \mathrm{W} \leq 1 \\
\mathrm{~W} & : \text { The number of prosperous } \\
& \begin{array}{l}
\text { households } \\
\text { spiritually rich) }
\end{array} \\
\mathrm{N} & : \text { The number of observed households. }
\end{aligned}
$$




\section{Material Poverty Index}

The Material Poverty Index $(\mathrm{Pm})$ is used to determine whether a household is in quadrant II, or the materially poor category. The value of the Material Poverty Index can be obtained using the following formula:

$$
P m=\frac{M p}{N}
$$

where

Pm : Material Poverty Index: $0 \leq \mathrm{Pm} \leq 1$

$\mathrm{Mp}$ : The number of materially poor but spiritually rich households

$\mathrm{N}$ : The population (observed households).

\section{Spiritual Poverty Index}

The Spiritual Poverty Index (Ps) is used to determine whether a household sits in quadrant III, or the spiritually poor category. The value of Ps can be obtained using the formula:

$$
\text { Ps }=\frac{S p}{N}
$$

where:

Ps : Spiritual Poverty Index: $0 \leq \mathrm{Ps} \leq 1$

$\mathrm{Sp}$ : The number of spiritually poor but materially sufficient households

$\mathrm{N}$ : Total population of observed households.

\section{Absolute Poverty Index}

The Absolute Poverty Index $(\mathrm{Pa})$ is used to determine whether a households is included in quadrant IV, or the absolute poverty category. The value of $\mathrm{Pa}$ is obtained using the following formula:

$$
P a=\frac{A p}{N}
$$

where:

$\mathrm{Pa}$ : Absolute Poverty Index: $0 \leq \mathrm{Pa} \leq 1$

Ap : The number of spiritually and materially poor households

$\mathrm{N}$ : Total population of observed households.

\section{RESULTS AND ANALYSIS}

\section{History of Jogokariyan Mosque}

Before 1967, Jogokariyan Village had only a small room measuring $3 \times 4$ meters square. It had high stairs and a deserted congregation. The room was located in a corner of the village, in RT 42 RW 11 (presently the house of Mr. Drs. Sugeng Dahlan). At that time, Jogokariyan communities were generally of the "abangan" group and preserved the kerjawen tradition. Jogokariyan Village emerged following displacement of the "Jogokariyo" troops from inside the Baluweti Fortress to the south or north of Panggung Krapyak. The area that subsequently became known as Jogokariyan Village was so named because of these troops. The villagers were demoted from the "abdi dalem" of Keraton to be weaving and batik factory workers due to a reduction in troop numbers at Keraton. There was a social and economic gap in Jogokariyan Village between the descendants of the Jogokariyo troops, who dominated the area, and the weaving and batik entrepreneurs. This condition coincided with the proliferation of the Indonesian Communist Party (PKI), when a lot of factory workers switched to become members of the party. This village was well known for its PKI ties. The G30S PKI tragedy of 1965 led to villagers who were active in the PKI being captured and arrested as political prisoners. It was at this time that Jogokariyan Mosque was established with the aim of maintaining relationships between villagers, as well as in a bid to attempt social change with Islamic culture. 
Jogokariyan Mosque is a place to carry out worship, and its establishment process was started on September 20, 1966 in Jogokariyan Village. It stands at No. 36 Jogokariyan Street and the name Jogokariyan Mosque was agreed upon by the founders and pioneers of dakwah, for the reasons outlined below:

1. Following sunnah of Rasulullah SAW, he named Quba Mosque as the first mosque in the world. This is because the mosque was built in Quba village. In addition, Bani Salamah Mosque was so named because it was built in Bani Salamah Village. But following a change in the direction of Qibla, this mosque came to be known more as Qiblatain Mosque.

2. A mosque is expected to have a clear area. With the name of "Jogokariyan" as its village name, this mosque has its own dakwah territory.

3. Jogokariyan Mosque can be a culturalbased unification tool in Jogokariyan Village, whereas previously, the area was divided into various sects and political movements. Therefore, the period of ishlah (improvement) began immediately after the liberation of the communities in the September 30, 1965 tragedy.

Jogokariyan Mosque always tries to develop the society and prosper the community through its vision and mission. Jogokariyan Mosque's vision is for the realization of a prosperous community inside and outside, and to be blessed by Allah SWT through its mosque activities. Its mission is for the mosque to serve as the center of all activities, to proliferate ubudiyah activities, serve as a place of spiritual recreation, as somewhere to obtain guidance for any problem, and for the mosque to contain a boarding school and college for the community.

\section{Jogokariyan Mosque Management}

The management of Jogokariyan Mosque are responsible for the strategic direction and practical elements of the management of the mosque, such as its mapping, serving, and empowerment. In terms of mapping, every mosque should have a clear map of dakwah, a clear area for its work, and registered congregants. The process of mapping consists of potential and necessity, possibility and challenge, and also strength and weakness. Jogokariyan Mosque Council (DKM) conducts a census to provide data for its database and a comprehensive map of dakwah. The database and dakwah map for Jogokariyan consist not only of the names of people but also their income, education, prayer or shalat activity, presence at Friday prayer in the mosque, Qurban in Eid al Adha, and zakat payment in Jogokariyan Baitul Maal Mosque, activity in the mosque, skill specification, and type of job. A map and data that are reported transparently can be used to help increase the number of people who come to participate in the mosque activities. Based on the data, an activity in the mosque can begin based on people's demand. DKM Jogokariyan is committed to not establishing a business unit in order to pertain to the community's business. Ukhuwah in Jogokariyan Mosque is built strongly. Jogokariyan Mosque accepts hundreds of guests every week, and meals for the guests are made by those households who have a restaurant.

\section{Jogokariyan Mosque Program}

The mosque nowadays serves as one of the economic empowerment centers for improving the welfare of mustahik. As the first winner of the pilot mosque competition in the Special Region of Yogyakarta 2016, Jogokariyan Mosque has many kinds of programs that can serve as a template for all mosques in Indonesia. These programs are as follows:

\section{Independent Congregant Movement}

In 2005, Jogokariyan Mosque initiated an independent congregant 
movement. Weekly dues are calculated from the funds needed in a year and then divided into 52 weeks. This is then divided again, by the mosque capacity, to give a cost per prayer area, and all of these calculations are communicated to the community. People are informed that if they pay that amount, they become an independent congregant. If they pay more, they are a subsidizing congregant. This program has been successful in increasing the weekly dues by 400 percent and has the effect of making people feel ashamed as to why they should have their worship activity subsidized.

\section{Subuh Together Movement}

Jogokariyan Mosque invites all congregants to come to the mosque with honor. In 2004, a new breakthrough program was launched asking people to crowd the mosque. Every house received a formal printed invitation card as if it were a wedding invitation. Every invitation had the recipient's name on it and contained a number of hadith on the exclusivity of shubuh prayer. The result was impressive, with a significant rise in congregant numbers. It can be seen from the amount of congregant was one third from the amount of Friday prayer.

\section{Jogokariyan Ramadhan Village}

This program runs during the month of Ramadhan and contains several activities. Firstly, tarawih ala Medina and tarawih ala Gaza. The committee invites imam originally from Medina and Gaza to broaden their knowledge about Muslims in the world through preaching after tarawih. Secondly, there is an invitation to break fasting together with approximately 1200 portions. Thirdly, there is the Ramadhan evening market. This is an entrepreneurial activity for the communities around the mosque who sell products in the streets of Jogokariyan. Someone who wishes to sell but does not have the capital to do so is able to request financing from the committee, which would be awarded from the baitul maal of the mosque with a qardh or hibah contract for those who meet the criteria.

\section{Zero Rupiah Infak Movement}

The management of Jogokariyan Mosque have also produced a financial system that differs from that of other mosques. While other mosques are always proud of announcing that their infak balance amounts to a couple of million, Jogokariyan Mosque always tries hard to reveal that its infak balance is almost always likely to be zero. For them, infak is to be allocated to doing good deeds, not for saving in the bank account. Even though it is unlikely that the balance could ever be zero, this serves as a motto for their strong will to distribute ZIS as soon as possible. The management of Jogokariyan Mosque adopts a very humanistic approach and really thinks about the daily problem of ummat. The announcement of an infak balance of millions would hurt if there was a neighbor who was unable to go to hospital due to them not having enough money, or if there were children who could not attend school. The management of Jogokariyan Mosque thus has the principle that hurting a congregant is a tragedy of dakwah. By announcing that their infak balance is almost zero, it is hoped that the congregants will be more enthusiastic about entrusting more of their wealth.

\section{Baitul Maal}

There are only a few mosques that have a baitul maal. The management of Jogokariyan Mosque made its 
baitul maal a reality due to the trust from ummat. Baitul maal is a program to collect ZIS funds and distribute them to a group of eight who deserve it (mustahik). The criterion for a mustahik to receive funds from the baitul maal at Jogokariyan Mosque is for them to be from a lower-class family. The fund can be stopped if people who are included by the criterion of mustahik do not carry out prayers diligently and do not follow any programs or studies at Jogokariyan Mosque.

In Jogokariyan Baitul Maal Mosque, the management is encouraged to understand ZIS as a mandate that shall be distributed so that the benefits and rewards can be achieved. Therefore, the distribution programs of Jogokariyan Baitul Maal Mosque are always creative, innovative, and reactive to the community's condition. The funds can be distributed in the form of both a consumptive and productive program. A consumptive program is a shortterm program aimed at fulfilling the main necessities of mustahik.
Examples of this type of program are the supplying of staple food needs when prices rise, the twice-weekly distribution of rice to the extremely indigent, the poor, and orphans, a monthly distribution of staple foods, education scholarship, medical service support, help for households who are trapped by debt, providing accommodation for wanderers who are out of funds, and volunteering for disasters, etc. A productive program is a long-term program that aims to empower mustahik so that they have social and economic endurance for use over the long term. An example of this type of program is capital financing for the community's businesses and consumption supply that is prepared by the communities.

\section{Mustahik Household Chief Characteristics}

A total of 100 respondents participated in this study, comprising mustahik who receive consumptive-type financing from a ZIS fund. The characteristics of the mustahik households as the respondents in this study are shown in Table 2 as follows.

Table 2. Mustahik Household Characteristics

\begin{tabular}{ccc}
\hline Characteristics & Frequency & Percentage \\
\hline Gender & 81 & 81 \\
Male & 19 & 19 \\
Female & 17 & 17 \\
Age & 64 & 64 \\
$15-40$ & 19 & 19 \\
$41-60$ & & \\
$>60$ & 4 & 4 \\
Formal Education & 28 & 28 \\
No Formal Education & 14 & 14 \\
Elementary School & 42 & 42 \\
Junior High School & 12 & 12 \\
Senior High School & & \\
$>$ Senior High School & 17 & 17 \\
Jobs & 39 & 39 \\
Employee & 30 & 30 \\
Entrepreneur & 14 & 14 \\
Labor & & \\
Others & &
\end{tabular}




\begin{tabular}{ccc}
\hline $1-3$ & 49 & 49 \\
$4-6$ & 48 & 48 \\
$>6$ & 3 & 3 \\
\hline
\end{tabular}

Source: Primary Data 2017 (processed)

According to Table 2, the majority of the receivers of ZIS financing from Jogokariyan Baitul Maal Mosque are male, comprising 81 people, or 81 percent, with 19 females, or 19 percent. A total of 81 percent are of a productive age, classed as 15 to 60 years, with the other 19 percent being older than 60 . In term of education, 4 percent of the mustahik did not attend school, 28 percent attended elementary school, with 14 and 42 percent for junior and senior high school, respectively. A total of 12 percent of the receivers had attended college.

Based on job type, 17 percent of the mustahik were employees, 39 percent were sellers or micro-entrepreneurs, 30 percent of the mustahik were laborers, and 14 percent worked in jobs other than those already mentioned, such as artist, crafter, etc. A total of 49 percent of the households had between 1 and 3 members. While 48 percent of the households comprised 4 to 6 members, and 3 percent of the mustahik had households containing more than six people.

Analysis of the Shift in Mustahik Households Before and After the ZIS Fund

Based on an analysis of the mustahiks' household condition before and after receiving the ZIS financial aid from Jogokariyan Baitul Maal Mosque, using the CIBEST model, there were shifts in the proportion of mustahik households within each CIBEST quadrant. These shifts can be seen in Table 3 below.

Table 3. The shifting of mustahik households

\begin{tabular}{|c|c|c|}
\hline \multirow{2}{*}{ Quadrant } & \multicolumn{2}{|c|}{ The number of mustahik households } \\
\hline & Before & After \\
\hline $\begin{array}{l}\text { Quadrant 1 } \\
\text { (Prosperous) }\end{array}$ & 60 & 81 \\
\hline $\begin{array}{l}\text { Quadrant II } \\
\text { (Materially Poor) }\end{array}$ & 38 & 19 \\
\hline $\begin{array}{l}\text { Quadrant III } \\
\text { (Spiritually Poor) }\end{array}$ & 1 & 0 \\
\hline $\begin{array}{l}\text { Quadrant IV } \\
\text { (Absolutely Poor) }\end{array}$ & 1 & 0 \\
\hline
\end{tabular}

Table 3 illustrates the shifts in the number of households in each quadrant. In quadrant I, there was an upward shift in the number of mustahik households categorized as prosperous households following the ZIS financial aid. The number of mustahik before the ZIS financial aid totaled 60 households. After the ZIS financial aid, the number increased to 81 households.
There was a decarese in the number of mustahik households in quadrant II, which are categorized as materially poor. Thus, 38 mustahik households were classed as spiritually rich but materially poor prior to the financial aid, which fell to 19 households after the ZIS financial aid. This decrease in the number of mustahik households categorized as materially poor thus indicates that ZIS financial aid from 
Jogokariyan Baitul Maal Mosque can fix the material side of mustahiks' life.

There was a decrease in the number of mustahik households in quadrant III, categorized as spiritually poor. There was one such mustahik household classed as fulfilling its material but not its spiritual needs, which fell to zero households after the ZIS financial aid. This indicates that ZIS financial aid can also be used to fix the spiritual side of mustahiks' life.

The last quadrant, quadrant IV, is for households that are categorized as being in absolute poverty, whereby they are unable to fulfill either their material or spiritual needs. There was only one household categorized as such prior to the ZIS financial aid, which subsequently fell to zero. This therefore means that the financial aid may help to eradicate absolute poverty. Generally, ZIS funds can increase the number of prosperous households and reduce the number of materially, spiritually, and absolutely poor households.

\section{Analysis of the Islamic Poverty Index}

The Islamic poverty index in the CIBEST model consists of the welfare index, material poverty index, spiritual poverty index, and absolute poverty index. Based on the analysis on CIBEST, the number of households in each category has already been determined. The results for the Islamic poverty index calculation will be obtained through the CIBEST quadrant. The Islamic poverty index calculations are shown as follows:

Table 4. Islamic Poverty Index

\begin{tabular}{cccccccc}
\hline & Poverty & \multicolumn{3}{c}{ Before the existence of ZIS fund } & \multicolumn{3}{c}{ After the existence of ZIS fund } \\
\cline { 2 - 7 } & Index & $\begin{array}{c}\text { Spiritual } \\
\text { Score }\end{array}$ & $\begin{array}{c}\text { Income } \\
(\mathrm{Rp})\end{array}$ & $\begin{array}{c}\text { Index } \\
\text { value }\end{array}$ & $\begin{array}{c}\text { Spiritual } \\
\text { Score }\end{array}$ & $\begin{array}{c}\text { Income } \\
(\mathrm{Rp})\end{array}$ & $\begin{array}{c}\text { Index } \\
\text { value }\end{array}$ \\
\hline 1 & $\begin{array}{c}\text { Welfare } \\
\text { Index }\end{array}$ & 3.54 & 1645576 & 0.60 & 4.276 & 1738120 & 0.81 \\
2 & $\begin{array}{c}\text { Material } \\
\text { Poverty } \\
\text { Index }\end{array}$ & 3.52 & 1524538 & 0.38 & 4.252 & 1600131 & 0.19 \\
3 & $\begin{array}{c}\text { Spiritual } \\
\text { Poverty } \\
\text { Indeks }\end{array}$ & 3 & 2000000 & 0.01 & 0 & 0 & 0 \\
4 & $\begin{array}{c}\text { Absolute } \\
\text { Poverty } \\
\text { Index }\end{array}$ & 3 & 500000 & 0.01 & 0 & 0 & 0 \\
\hline
\end{tabular}

Source: Primary Data 2017 (processed)

\section{Analysis of the Mustahik Household Welfare Index}

The welfare index describes the number of mustahik households that are categorized as prosperous households. Table 4 shows that there was an increase in the average spiritual score of mustahik households of as much as 0.736 . The average income of mustahik also increased by Rp. 92544.
The index value for mustahik household welfare also increased by up to 21 percent. These results indicate that the distribution and empowerment of ZIS funds could enhance the welfare index of mustahik households. 
Analysis of the Material Poverty Index of Mustahik Households

The material poverty index describes the number of mustahik households that are categorized as materially poor but spiritually rich. Based on Table 4, there was an increase in the average spiritual score of mustahik households of as much as 0.732 . There was also a significant improvement in the average income, increasing by up to Rp. 75 593. The index value of material poverty fell by 19 percent. These results show that the distribution and empowerment of ZIS funds could reduce the material poverty index.

\section{Analysis of the Spiritual Poverty Index of Mustahik Households}

The spiritual poverty index describes the number of mustahik households that are categorized as spiritually poor but materially rich. Based on Table 4, there was a decrease in the average spiritual score of mustahik to zero, as well as in the average income of mustahik. The index value of spiritual poverty also fell to one percent. These results show that the distribution and empowerment of ZIS funds can reduce the spiritual poverty index.

\section{Analysis of the Absolute Poverty Index of Mustahik Households}

The absolute poverty index describes the number of mustahik households that are categorized as both materially and spiritually poor. Based on Table 4, the average for the spiritual score fell to zero, as well as the average income of mustahik households. The poverty index value also fell to one percent. These results show that the distribution and empowerment of ZIS funds can reduce the absolute poverty index.

\section{CONCLUSION AND RECOMMENDATION}

Mustahik households, as the receivers of ZIS funds, have experienced a welfare enhancement of 21 percent and falls in material poverty of 19 percent, spiritual poverty of 1 percent, and in absolute poverty of 1 percent. These results can be seen from the changes in the CIBEST Islamic Poverty Index.

A well-managed mosque is thus able to decrease poverty and improve the welfare of mustahik. The distribution and empowerment programs from Jogokariyan Baitul Maal Mosque include the following: supplying staple food needs when the price rises, distribution of rice twice a week to the extremely indigent, the poor, and orphans, distribution of staple foods once a month, education scholarship, medical service support, help for households trapped by debt, accommodation for wanderers who are out of money, volunteering in disasters, etc. The criterion for a mustahik receiver from Jogokariyan Baitul Maal Mosque is a lower-class family. The funds can be stopped if people who are included as mustahik do not diligently perform prayers and do not follow programs or studies at Jogokariyan Mosque.

The existence of a mosque as a zakat institution, or the existence within a mosque of a particular institution to manage zakat, infak, and sadaqah, has a large potential to collect ZIS funds from the community. The potential of ZIS funds triggers the ZIS management to work more professionally. Jogokariyan Baitul Maal Mosque should pay attention to both the material and spiritual sides. The spirit of transparent, trusted, and professional should be upheld by the ZIS management in order to gain a greater level of trust from the community. The mosque committee always tries to find other sources of ZIS funds to enable it to increase the amount of ZIS receivers; 
therefore, ZIS can be distributed more widely, outside Jogokariyan. The government should also support the mosque's programs in optimizing the collection and distribution of ZIS funds. The government could cooperate with the mosque in managing funds for the welfare of society.

\section{REFERENCES}

Beik, I. S., \& Arsyianti, L. D. (2015). Construction of CIBEST model as measurement of poverty and welfare indices from Islamic perspective. Al-iqtishad, VII(1) [Internet]. [downloaded 2017 Mei 22].

\section{Ekonomi}

Pembangunan Syariah. Jakarta (ID). Rajawali Pers.

[BPS] Badan Pusat Statistik (ID). 2015. Jumlah Penduduk Miskin dan Garis Kemiskinaan menurut

Kabupaten/Kota Yogyakarat, 20142015. [downloaded 2017 April 02]. Retrieved from: http://www.yogyakarta.bps.go.id

Mushlihah, N. (2016). Analisis Dampak Pendistribusian Dana Zakat Sebagai Pengurang Kemiskinan dengan Menggunakan Model CIBEST: Studi Kasus LAZ PM Al-Bunyan [skripsi]. Bogor (ID): Institut Pertanian Bogor.

Pratama, C. (2015). Pendayagunaan Zakat Produktif dalam Mengurangi Kemiskinan Berdasarkan CIBEST Model: Studi Kasus PT Masyarakat Mandiri LAZ PM Al-Bunyan [skripsi]. Bogor (ID): Institut Pertanian Bogor.

[SIMAS KEMENAG] Sistem Informasi Masjid Kementerian Agama (ID). (2017). Hasil Pencarian Masjid. [downloaded 2017 Juli]. Retrieved from:

http://simas.kemenag.go.id/index.ph p/search/?provinsi_id=15\&kabupate n_id=229\&kecamatan_id=\&tipologi _id=\&keyword=yogyakarta\&filter $=F$ ILTER

Tsani, T. (2010). Analisis Dampak Distribusi Zakat terhadap Tingkat Kemiskinan dan Kesenjangan Pendapatan: Studi Kasus Pendayagunaan Zakat oleh BAZDA Lampung Selatan [skripsi]. Bogor (ID): Institut Pertanian Bogor.

Wibisono, Y. (2016). Potensi Zakat Nasional: Peluang dan Tantangan Pengelolaan disampaikan pada Seminar Nasional Zakat 2016. Tersedia pada: http://www.puskasbaznas.com/image s/ppt/Panel_1_Yusuf_Wibisono.pdf

Salahuddin El Ayyubi

Bogor Agricultural University

Indonesia

djibran@apps.ipb.co.id

Henni Eka Saputri

Bogor Agricultural University

Indonesia

saputrihennieka@gmail.com 